\title{
FAKTOR YANG MEMPENGARUHI PERILAKU 3M DALAM PENCEGAHAN PENULARAN COVID - 19 DI PADUKUHAN NGALIYAN
}

(Factors that Affect the Behavior of 3M In the Prevention of Transmission of Covid - 19 In Padukuhan Ngaliyan )

\section{Jamroni $^{1 *}$, Avifah Fitrianingrum ${ }^{1}$}

1Program Studi Kesehatan Masyarakat STIKes Surya Global Yogyakarta

*Koresponden Penulis: pakdejamkom@gmail.com

\begin{abstract}
ABSTRAK
Pandemi Covid-19 saat ini menjadi masalah kesehatan terbesar di dunia. Kampanye 3M merupakan satu paket protokol kesehatan untuk mencegah penularan COVID-19. Berdasarkan studi pendahuluan dengan observasi langsung di Padukuhan Ngaliyan diketahui bahwa masih ada beberapa masyarakat yang tidak menerapkan perilaku 3M. Tujuan Penelitian adalah untuk mengetahui faktor-faktor apa yang mempengaruhi perilaku 3M (Mencuci tangan, Memakai masker, Menjaga jarak) dalam pencegahan penularan COVID-19 di Padukuhan Ngaliyan. Jenis penelitian ini adalah penelitian kuantitatif dengan desain penelitian adalah cross sectional. Teknik pengambilan sampel dengan random sampling sebanyak 89 responden. Data dianalisis menggunakan uji Chi-Square. Berdasarkan uji chi square variabel pengetahuan terhadap perilaku 3M diperoleh $p$-value $0,013(<0,05)$, variabel sikap p-value $0,027(<0,05)$ dan variabel media informasi $0,020(<0,05)$. Kesimpulan penelitian ini yaitu ada pengaruh yang signifikan antara pengetahuan, sikap dan media informasi terhadap perilaku 3M di Padukuhan Ngaliyan.
\end{abstract}

Kata Kunci : Media informasi, pengetahuan, perilaku 3M, sikap

\section{ABSTRACT}

Pandemic Covid-19, is to be the biggest health problems in the world. Campaign 3M is one package the protocol of health to prevent the transmission of COVID-19. Based on preliminary studies with direct observation in Padukuhan Ngaliyan be aware that there are still some people who do not implement the behavior of 3M. The purpose of the Study was to determine what factors affect the behavior of 3M (Wash hands, Wear a mask, Keep a distance) in the prevention of transmission of COVID-19 in Padukuhan Ngaliyan. This type of research is quantitative research with the research design was cross-sectional. Sampling technique with random sampling as many as 89 respondents. Data were analyzed using Chi-Square test. Based on the chi square test variable knowledge of the behavior of $3 M$ obtained the value of p-value 0,013 (<0.05), attitude $0.02(<0.05)$ and media information $0.020(<0,05)$. The conclusion of this research that there is a significant influence between knowledge, attitudes and media information on the behavior of $3 M$ in Padukuhan Ngaliyan.

Keywords: Attitude, behavior 3M, knowledge, media information

\section{PENDAHULUAN}

Pandemi Covid-19 saat ini menjadi masalah kesehatan terbesar di dunia. WHO (World Health Organization atau Badan Kesehatan Dunia) secara resmi menetapkan virus corona (COVID-19) sebagai pandemi pada tanggal 11 Maret 2020.. 
Peningkatan jumlah kasus berlangsung cukup cepat, dan menyebar ke berbagai negara dalam waktu singkat. Sampai pada 13 Januari 2021, WHO melaporkan 91.969.631 kasus terkonfirmasi dengan 1.968.265 kematian di seluruh dunia (CFR 2,1\%). Indonesia melaporkan kasus pertama pada tanggal 2 Maret 2020. Kasus meningkat dan menyebar dengan cepat ke seluruh wilayah Indonesia. Sampai dengan tanggal 12 Januari 2021 Kementerian Kesehatan melaporkan 846.765 kasus konfirmasi COVID-19 dengan 24.645 kasus meninggal (CFR 2,9\%). Dari situasi tersebut Pemerintah Indonesia telah menetapkan Keputusan Presiden Nomor 11 Tahun 2020 tentang Penetapan Kedaruratan Kesehatan Masyarakat Corona Virus Dieases (COVID-19).

Masyarakat memiliki peran penting dalam memutus mata rantai penularan COVID19 agar tidak menimbulkan sumber penularan baru. Mengingat cara penularannya berdasarkan droplet infection dari individu ke individu, maka penularan dapat terjadi baik di rumah, perjalanan, tempat kerja, tempat ibadah, tempat wisata maupun tempat lain dimana terdapat orang berinteraksi sosial. Untuk itu pencegahan penularan COVID19 pada individu dilakukan dengan beberapa tindakan, seperti membersihkan tangan secara teratur dengan mencuci tangan, menggunakan alat pelindung diri berupa masker dan menjaga jarak minimal 1 meter dengan orang lain yang biasa dikenal dengan program 3M (Kemenkes RI, 2020).

Sejak Indonesia dinyatakan terdapat kasus terkonfirmasi COVID- 19, berbagai wilayah provinsi mulai mewaspadai adanya kasus tersebut di daerahnya. Salah satunya di Daerah Istimewa Yogyakarta, dengan terdapatnya kasus terkonfirmasi COVID-19 pada tanggal 26 Maret 2020 melalui Keputusan Gubernur Daerah Istimewa Yogyakarta Nomor 65 Tahun 2020 menetapkan Status Tanggap Darurat Bencana Corona Virus Dieases 19 (COVID-19) di Daerah Istimewa Yogyakarta, mulai tanggal 20 Maret 2020 sampai 29 Mei 2020 dan diperpanjang melalui Keputusan Gubernur Daerah Istimewa Yogyakarta Nomor 121 Tahun 2020 mulai tanggal 30 Mei 2020 sampai 30 Juni 2020 (Dinkes DIY, 2021).

Daerah istimewa Yogyakarta tercatat sudah terjadi 16092 total konfirmasi COVID19 dengan pembagian 68,15\% dirawat, 1,87\% meninggal dan 29,98\% sembuh dangan total suspek 26.288. Kasus COVID-19 masih terus meningkat walaupun diiringi dengan angka kesembuhan namun hal ini tetap menjadi perhatian di Kabupaten Kota Yogyakarta tercatat dirawat 980, meninggal 92 dan sembuh 1879, Kabupaten Sleman tercatat dirawat 1710, meninggal 103 dan sembuh 4291, Kabupaten Bantul tercatat dirawat 1520, meninggal 100 dan sembuh 2976, di Kabupaten Gunung Kidul tercatat dirawat 412, meninggal 34 dan sembuh 691 sedangkan di Kulon Progo mencapai terkonfirmasi dirawat 556, meninggal 20 dan sembuh 684 pada data yang diperbarui tanggal 13 Januari 2021 (Dinkes DIY, 2021).

Tujuan penelitian ini untuk mengetahui faktor-faktor apa yang mempengaruhi perilaku 3M (Mencuci tangan, Memakai masker, Menjaga jarak) dalam pencegahan penularan COVID-19 di Padukuhan Ngaliyan.

\section{METODE PENELITIAN}

Jenis penelitian ini adalah penelitian analitik dengan rancangan cross sectional. Lokasi penelitian di Padukuhan Ngaliyan Desa Ngargosari Samigaluh Kulonprogo Yogyakarta. Populasi dalam penelitian ini adalah masyarakat Padukuhan Ngaliyan Yogyakarta, dengan jumlah populasi sebesar 746 jiwa. Teknik sampling yaitu probability sampling dengan menggunakan rumus slovin diperoleh hasil sampel sebanyak 89 responden. Pengumpulan data dengan menyebarkan kuesioner. Analisis data menggunakan uji chi-square. 


\section{HASIL}

Jumlah responden dalam penelitian ini sebanyak 89 responden. Responden dalam penelitian ini adalah warga Padukuhan Ngaliyan. Identitas responden ditinjau berdasarkan jenis kelamin, umur, pendidikan terakhir dan pekerjaan. Hasil pengelompokan responden penelitian sebagai berikut :

Tabel 1. Karakteristik Responden Pada Warga Padukuhan Ngaliyan Tahun 2021

\begin{tabular}{lcc}
\hline \multicolumn{1}{c}{ Karakteristik } & $\mathbf{N}$ & $\mathbf{\%}$ \\
\hline Jenis Kelamin & & \\
Laki-laki & 31 & 34,83 \\
Perempuan & 58 & 65,17 \\
17-25 & 17 & 19,1 \\
$26-45$ & 47 & 52,8 \\
46-65 & 25 & 28,1 \\
Pendidikan terakhir & & \\
SD/Sederajat & 6 & 6,7 \\
SMP/Sederajat & 12 & 13,5 \\
SMA/SMK/Sederajat & 56 & 62,9 \\
D2 & 1 & 1,1 \\
S1 & 13 & 14,6 \\
S2 & 1 & 1,1 \\
Pekerjaan & & \\
Belum Bekerja & 1 & 1,1 \\
Buruh & 5 & 5,6 \\
Guru & 1 & 1,1 \\
Ibu Rumah Tangga & 29 & 32,6 \\
Swasta & 15 & 16,9 \\
Perangkat Desa & 3 & 3,4 \\
Pedagang & 3 & 3,4 \\
Pelajar/Mahasiswa & 5 & 5,6 \\
Pensiun & 2 & 2,2 \\
Petani & 21 & 23,6 \\
PNS & 3 & 3,4 \\
Wiraswasta & 1 & 1,1 \\
\hline
\end{tabular}

Berdasarkan tabel 1 dari jumlah 89 responden didapatkan data jenis kelamin responden sebagian besar berjenis kelamin perempuan yaitu sebanyak 58 responden $(65,17 \%)$ dan berjenis kelamin laki-laki yaitu sebanyak 31 responden $(34,83 \%)$. Karakteristik umur sebagian besar 26-45 tahun yaitu sebanyak 47 responden $\quad$ (52,8\%), selanjutnya umur 46-65 tahun sebanyak 25 responden $(28,1 \%)$ dan umur 17-25 tahun yaitu sebanyak 17 responden (19,1\%). pendidikan terakhir responden sebagian besar yaitu SMA/SMK/Sederajat dengan jumlah 56 responden $(62,9 \%)$, selanjutnya S1 dan SMP/Sederajat dengan jumlah 13 responden (14,6\%) dan 12 responden $(13,5 \%)$, SD/Sederajat dengan jumlah 6 responden $(6,7 \%)$ dan D2 serta S2 memiliki jumlah yang sama yaitu sebanyak 1 responden $(1,1 \%)$. Sebagian besar responden memiliki pekerjaan sebagai ibu rumah tangga dengan jumlah 29 responden $(32,6 \%)$, selanjutnya petani degan jumlah 21 responden $(23,6 \%)$, swasta dengan jumlah 15 responden $(16,9 \%)$, Buruh dan pelajar/mahasiswa dengan jumlah yang sama masing-masing yaitu 5 responden $(5,6 \%)$, PNS, pedagang dan perangkat desa dengan jumlah yang sama masing-masing yaitu 3 responden $(3,4 \%)$ kemudian wiraswasta dan belum bekerja dengan jumlah yang sama masing- masing sebanyak 1 responden $(1,1 \%)$. Hasil uji statistik univariat pada variabel faktor pengetahuan 
didapatkan hasil sebagai berikut :

Tabel 2 Distribusi Frekuensi Faktor Pengetahuan Pada Warga Padukuhan Ngaliyan Ngargosari, Samigaluh Kulon Progo Tahun 2021

\begin{tabular}{|c|c|c|}
\hline Variabel & $\mathbf{N}$ & $\%$ \\
\hline \multicolumn{3}{|l|}{ Faktor Pengetahuan } \\
\hline Baik & 61 & 68,5 \\
\hline Tidak Baik & 28 & 31,5 \\
\hline \multicolumn{3}{|l|}{ Faktor Sikap } \\
\hline Baik & 23 & 25,8 \\
\hline Cukup & 56 & 62,9 \\
\hline Kurang & 10 & 11,2 \\
\hline \multicolumn{3}{|l|}{ Media } \\
\hline Baik & 3 & 3,4 \\
\hline Cukup & 74 & 83,1 \\
\hline Kurang & 12 & 13,5 \\
\hline \multicolumn{3}{|l|}{ Perilaku 3M } \\
\hline Baik & 74 & 83,1 \\
\hline Tidak Baik & 15 & 16,9 \\
\hline
\end{tabular}

Berasarkan tabel 2 dari 89 responden didapatkan hasil bahwa faktor pengetahuan pada warga Padukuhan Ngaliyan dalam kategori baik sebanyak 61 responden dengan persentase 68,5\% dan untuk kategori tidak baik sebanyak 28 responden dengan persentase 31,5\%. Sehingga dapat disimpulkan bahwa faktor pengetahuan pada warga Padukuhan Ngaliyan dalam kategori baik.

Faktor sikap pada warga Padukuhan Ngaliyan dalam kategori baik sebanyak 23 responden dengan persentase 25,8\%, kategori cukup sebanyak 56 responden dengan persentase 62,9\% dan kategori kurang sebanyak 10 dengan persentase 11,2\%. Sehingga dapat disimpulkan bahwa faktor sikap pada warga Padukuhan Ngaliyan dalam kategori cukup.

Faktor media informasi pada warga Padukuhan Ngaliyan dalam kategori baik terdapat 3 responden dengan persentase 3,4\%, kategori cukup sebanyak 74 responden dengan persentase 83,1\% dan kategori kurang sebanyak 12 responden dengan persentase $13,5 \%$. Sehingga dapat disimpulkan bahwa variabel faktor media informasi pada warga Padukuhan Ngaliyan dalam kategori cukup.

Variabel perilaku 3M pada warga Padukuhan Ngaliyan dalam kategori baik sebanyak 74 responden dengan persentase 83,1\% dan kategori tidak baik sebanyak 15 responden dengan persentase 16,9\%. Sehingga dapat disimpulkan bahwa variabel perilaku 3M pada warga Padukuhan Ngaliyan dalam kategori baik.

Analisis bivariat data dalam penelitian ini bertujuan untuk mengetahui ada atau tidaknya pengaruh antara variabel independen dengan variabel dependen dengan menggunakan uji Chi-Square. Data yang didapatkan setelah uji korelasi menggunakan spss 20.0. Hasil uji statistik dengan uji Chi-Square pada variabel faktor pengetahuan, sikap dan media terhadap perilaku 3M dapat dilihat pada table 3.

Berdasarkan tabel 3 hasil analisis uji Chi-Square faktor pengetahuan terhadap perilaku 3M diperoleh harga $\mathrm{X}^{2}$ hitung sebesar 19,712 dan $\mathrm{DF}=1$. Berdasarkan tabel ChiSquare dengan $\mathrm{DF}=1$ dan taraf signifikansi 5\% $(0,05)$ diperoleh $\mathrm{X}^{2}$ tabel sebesar 3,841. Oleh karena $\mathrm{X}^{2}$ hitung $>\mathrm{X}^{2}$ tabel $(19,712>3,841)$ maka dapat dinyatakan terdapat pengaruh signifikan antara faktor pengetahuan terhadap perilaku 3M pada warga Padukuhan Ngaliyan Tahun 2021. Hasil lain yang dapat dijelaskan dari tabel adalah nilai $P$ sebesar 0,000. Oleh karena nilai $\mathrm{P}<0,05$ maka dapat dinyatakan bahwa terdapat pengaruh signifikann antara faktor pengetahuan terhadap perilaku $3 \mathrm{M}$ pada warga 
Padukuhan Ngaliyan Tahun 2021.

Analisis uji Chi-Square faktor sikap terhadap perilaku 3M diperoleh harga $\mathrm{X}^{2}$ hitung sebesar 58,411 dan DF= 2. Berdasarkan tabel Chi- Square dengan DF $=2$ dan taraf signifikansi 5\% $(0,05)$ diperoleh $X^{2}$ tabel sebesar 5,991 Oleh karena $X^{2}$ hitung $>X^{2}$ tabel $(58,411>5,991)$ maka dapat dinyatakan terdapat pengaruh signifikan antara faktor sikap terhadap perilaku 3M pada warga Padukuhan Ngaliyan Tahun 2021. Hasil lain yang dapat dijelaskan dari tabel adalah nilai $\mathrm{P}$ sebesar 0,000. Oleh karena nilai $\mathrm{P}<0,05$ maka dapat dinyatakan bahwa terdapat pengaruh signifikan antara faktor sikap terhadap perilaku $3 \mathrm{M}$ pada warga Padukuhan Ngaliyan Tahun 2021.

Tabel 3. Hasil Uji Chi-Square Pengaruh Faktor Pengetahuan Terhadap perilaku 3M Pada Warga Padukuhan Ngaliyan Tahun 2021

\begin{tabular}{lccc}
\hline \multicolumn{1}{c}{ Variabel } & $\mathbf{N}$ & $\mathbf{X}^{\mathbf{2}}$ & $\boldsymbol{p}$-Value \\
\hline Pengetahuan & $58,411^{\underline{a}}$ & $58,411^{\underline{a}}$ & 0,000 \\
Sikap & 49,448 & 49,448 & 0,000 \\
Media & $33,599 \underline{a}$ & $33,599 \underline{a}$ & 0,000 \\
\hline
\end{tabular}

Hasil analisis uji Chi-Square faktor media informasi terhadap perilaku 3M diperoleh harga $\mathrm{X}^{2}$ hitung sebesar 33,599 dan $\mathrm{DF}=2$. Berdasarkan tabel Chi-Square dengan DF = 2 dan taraf signifikansi $5 \%(0,05)$ diperoleh $X^{2}$ tabel sebesar 33,599. Oleh karena $X^{2}$ hitung $>X^{2}$ tabel $(33,599>5,991)$ maka dapat dinyatakan terdapat pengaruh signifikan antara faktor media informasi terhadap perilaku $3 \mathrm{M}$ pada warga Padukuhan Ngaliyan Tahun 2021. Hasil lain yang dapat dijelaskan dari tabel adalah nilai $\mathrm{P}$ sebesar 0,000 . Oleh karena nilai $\mathrm{P}<0,05$ maka dapat dinyatakan bahwa terdapat pengaruh signifikan antara faktor media informasi terhadap perilaku $3 \mathrm{M}$ pada warga Padukuhan Ngaliyan Tahun 2021.

\section{PEMBAHASAN}

Penelitian ini untuk mengetahui pengetahuan terhadap perilaku 3M (mencuci tangan, memakai masker, menjaga jarak) pada warga Padukuhan Ngaliyan, untuk mengetahui sikap terhadap perilaku 3M (mencuci tangan, memakai masker, menjaga jarak) pada warga Padukuhan Ngaliyan, dan untuk mengetahui media informasi terhadap perilaku 3M (mencuci tangan, memakai masker, menjaga jarak) pada warga Padukuhan Ngaliyan Tahun 2021. Dalam penelitian ini peneliti menggunakan pendekatan cross sectional dengan analisis data menggunakan uji Chi-Square yang dilakukan oleh peneliti diatas dapat diketahui bahwa ada hipotesis yang diajukan oleh peneliti yakni hipotesis pengetahuan, sikap dan media informasi terhadap perilaku $3 \mathrm{M}$ (mencuci tangan, memakai masker, menjaga jarak).

pengetahuan terhadap perilaku 3M menunjukkan bahwa nilai tabel P (Asymp.Sig) sebesar 0,000. Oleh karena nilai $\mathrm{P}<0,05$ maka dapat dinyatakan bahwa terdapat pengaruh yang signifikan antara pengetahuan terhadap perilaku 3M pada warga Padukuhan Ngaliyan Tahun 2021. Hal ini dapat dibuktikan bahwa responden yang memiliki pengetahuan yang baik akan berpengaruh terhadap perilaku 3M yang baik pula, begitu sebaliknya jika responden tidak memiliki pengetahuan yang baik akan berpengaruh terhadap perilaku 3M yang tidak baik pula.

Hasil penelitian ini sejalan dengan penelitian Norita, dkk (2020) dengan judul Hubungan Pengetahuan dan Sikap dengan Kepatuhan untuk Menjaga Jarak dan Menggunakan Masker pada Masyarakat Di Kota Barabai Kabupaten Hulu Sungai Tengah Tahun 2020. Didapatkan hasil uji statistik nilai $p=0,010(p<0,05)$ yang artinya ada hubungan antara pengetahuan dengan kepatuhan menjaga jarak dan menggunakan 
masker pada masyarakat di Kota Barabai Kabupaten Hulu Sungai Tengah Tahun 2020 (Norita dkk, 2020).

Menurut Notoatmodjo (2011) menyatakan faktor-faktor yang mempengaruhi terbentuknya perilaku dibedakan menjadi dua, yakni faktor-faktor internal dan eksternal. Faktor internal mencakup: pengetahuan, kecerdasan, persepsi, emosi, motivasi dan sebagainya yang berfungsi untuk mengolah rangsangan dari luar. Sedangkan faktor ekstern meliputi lingkungan sekitar, baik fisik maupun nonfisik seperti: iklim, manusia, social- ekonomi, kebudayaan, dan sebagainya. Apabila penerimaan perilaku baru atau adopsi perilaku melalui proses kesadaran, merasa tertarik, menimbang-nimbang, subjek mulai mencoba sampai dimana subjek telah berperilaku baru, dimana didasari dengan pengetahuan dan sikap yang positif maka perilaku tersebut akan bersifat langgeng (long lasting). Sebaliknya, apabila perilaku itu tidak didasari oleh pengetahuan dan kesadaran akan tidak berlangsung lama (Notoatmojo, 2011).

Hasil analisis pengaruh sikap terhadap perilaku 3M menunjukkan bahwa nilai tabel $\mathrm{P}$ (Asymp.Sig) sebesar 0,000. Oleh karena nilai $\mathrm{P}<0,05$ maka dapat dinyatakan bahwa terdapat pengaruh yang signifikan antara sikap terhadap perilaku $3 \mathrm{M}$ pada warga Padukuhan Ngaliyan Tahun 2021. Hal ini dapat dibuktikan bahwa responden yang memiliki sikap yang baik akan berpengaruh terhadap perilaku 3M yang baik dan responden yang memiliki sikap yang cukup akan berpengaruh terhadap perilaku 3M yang baik pula.

Hasil penelitian ini sejalan dengan penelitian Lestari (2019) dengan judul penelitian "Hubungan Pengetahuan dan Sikap Terhadap Perilaku Cuci Tangan Pada Masyarakat Kelurahan Pegirian". Didapatkan hasil uji statistik yaitu dengan hasil p value sebesar 0,017 dan kuat hubungan bersifat kuat denan koefisien sebesar 0,271 sehingga dapat dinyatakan terdapat hubungan antara sikap dengan perilaku cuci tangan masyarakat Kelurahan Pegirian (Lestari, 2019).

Hasil penelitian ini sejalan dengan penelitian Suprayitno, dkk (2020) dengan judul " Pengetahuan dan Sikap Masyarakat dalam Pencegahan COVID-19". Didapatkan hasil uji statistik yakni sebanyak 53 orang 85,5\% menghasilkan sikap yang positif artinya dalam penelitian ini sikap masyarakat dalam pencegahan COVID-19 dengan perilaku mencuci tangan dan memakai masker sebagian besar positif (Suprayitno dkk, 2020).

Hasil penelitian lain dari penelitian Utami, dkk (2020) dengan judul Pengetahuan, Sikap dan Keterampilan Masyarakat Dalam Pencegahan COVID-19 di Provinsi DKI Jakarta. Didapatkan hasil data analisis menggunakan deskriptif bahwa 70,7\% responden memiliki sikap yang baik dalam pencegahan COVID-19 dan 29,3\% memiliki sikap yang kurang dalam pencegahan COVID-19. Maka dapat diartikan bahwa masyarakat memiliki sikap yang baik dalam melakukan pencegahan COVID-19 (Utami dkk, 2020).

Menurut Notoatmodjo (2011) menyatakan terbentuknya suatu perilaku baru, terutama pada subjek dewasa dimulai pada domain kognitif, dalam arti subjek tahu terlebih dahulu terhadap stimulus yang berupa materi atau objek di luarnya. Kemudian menimbulkan pengetahuan baru pada subjek tersebut, dan selanjutnya menimbulkan respon batin dalam bentuk sikap subjek terhadap objek yang diketahui (Notoatmojo, 2011).

Hasil analisis pengaruh media informasi terhadap perilaku 3M menunjukkan bahwa nilai tabel $\mathrm{P}$ (Asymp.Sig) sebesar 0,000. Oleh karena nilai $\mathrm{P}<0,05$ maka dapat dinyatakan bahwa terdapat pengaruh yang signifikan antara media informasi terhadap perilaku 3M pada warga Padukuhan Ngaliyan Tahun 2021. Hal ini dapat dibuktikan 
bahwa responden yang memiliki media informasi yang baik dan cukup akan berpengaruh terhadap perilaku 3M yang baik, begitu sebaliknya jika responden tidak memiliki media informasi yang cukup atau kurang maka akan berpengaruh terhadap perilaku 3M yang tidak baik.

Hasil penelitian ini sejalan dengan penelitian Kundaryanti, dkk (2020) dengan judul penelitian "Faktor-faktor yang Berhubungan dengan Perilaku Pencegahan Penularan COVID-19 Pada Ibu Hamil Tahun 2020". Didapatkan hasil bahwa responden mendapakan informasi dari media cetak sebanyak $3(14,3 \%)$ mempunyai perilaku kurang terhadap pencegahan penularan COVID-19 dan 12 (85,75\%) yang berperilaku baik. Hasil uji statistik didapatkan p value 0,03 $<0,05$ yang berarti terdapat hubungan yang bermakna antara sumber informasi dengan perilaku pencegahan penularan COVID-19 (Kundaryanti dkk, 2020).

Hasil penelitian ini sejalan dengan jurnal pembelajaran pemberdayaan masyarakat Andriyansyah, dkk (2020) dengan judul Kampanye Pentingnya Himbauan Mencuci Tangan Melalui Media Pamflet di Masa Pandemi COVID-19”. Dengan melalui progam kerja KKN dalam bentuk kampanye melalui penyebaran pamphlet dan menyediakan fasilitas cuci tangan, didapatkan hasil bahwa adanya tingkat kesadaran masyarakat dan dukungan serta respon positif terhadap pentingnya mencuci tangan di masa pandemi COVID-19 (Andriyansyah, 2020).

Hasil penelitian ini sejalan dengan penelitian Jahrir, dkk (2020) dengan judul penelitian "Pengaruh Penggunaan Bahasa dalam Spanduk Lockdown Wilayah Terhadap Perilaku Sosial Masyarakat Pada Masa Pandemi COVID-19 di Kota Makassar". Didapatkan hasil tanggapan dari 70 responden lebih dominan mengatakan bahwa ada pengaruh penggunaan spanduk Lockdown terhadap aktivitas sosial masyarakat terutama mengenai social distancing dan physical distancing dengan jumlah persentase sebanyak (54,3\%) (Jahrir dkk, 2021).

Menurut teori Bakir (2007) dalam Iswanto dan Sulistyowati (2018) menjelaskan informasi memiliki ciri utama berupa konektivitas dengan internet. Masyarakat mulai bergantung dengan jaringan informasi elektronik. Masyarakat mengalokasikan waktu dan tenaga terpusat pada kegiatan informasi. Lebih dari itu, kini informasi dan pengetahuan mulai dianggap sebagai sumber daya dan faktor penentu produksi. Hal ini berdampak pada meningkatkan kebutuhan pada tenaga ahli informasi. Seseorang akan mencari informasi apabila ia memerlukan jawaban pertanyaan atau ingin mencari fakta atas suatu keadaan (Iswanto, 2018).

Pencarian informasi lambat laun berubah menjadi kebutuhan. Perubahan perilaku kesehatan melalui cara pendidikan dan promosi kesehatan ini diawali dengan cara pemberian informasi- informasi kesehatan. Dengan memberikan informasiinformasi tentang cara-cara mencapai hidup sehat, cara pemeliharaan kesehatan, cara menghindari penyakit, dan sebagainnya akan meningkatkan pengetahuan masyarakat tentang hal tersebut (Notoatmodjo, 2014).

\section{KESIMPULAN DAN SARAN}

Berdasarkan hasil penelitian dapat disimpulkan bahwa 1) Ada pengaruh yang signifikan antara faktor pengetahuan terhadap perilaku 3M (mencuci tangan, memakai masker, menjaga jarak) pada warga Padukuhan Ngaliyan tahun 2021. 2) Ada pengaruh yang signifikan antara faktor sikap terhadap perilaku 3M (mencuci tangan, memakai masker, menjaga jarak) pada warga Padukuhan Ngaliyan tahun 2021. 3) Ada pengaruh yang signifikan antara faktor media informasi terhadap perilaku 3M (mencuci tangan, memakai masker, menjaga jarak) pada warga Padukuhan Ngaliyan tahun 2021. 
Saran bagi masyarakat Padukuhan Ngaliyan, harus selalu mentaati protokol kesehatan yang telah ditetapkan pemerintah, begitupun dengan bagaimana masyarakat bersikap dengan adanya himbahuan untuk menerapkan perilaku 3M (mencuci tangan, memakai masker, menjaga jarak) sebagai upaya pencegahan penularan COVID-19. Bagi Peneliti lain yang ingin mengkaji permasalahan tentang faktor-faktor yang mempengaruhi perilaku 3M (mencuci tangan, memakai masker, menjaga jarak) dapat lebih dikembangkan dalam cakupan yang lebih luas penelitiannya dengan menggunakan variabel yang lain.

\section{UCAPAN TERIMA KASIH}

Peneliti mengucapkan terimakasih kepada STIKes Surya Global selaku Institusi payung kegiatan Tridharma perguruan Tinggi bagi Tenaga pendidiknya, juga terimakasih kepada warga Padukuhan Ngaliyan selaku responden dan lokasi pada penitian ini.

\section{DAFTAR PUSTAKA}

Andriyansyah, M. (2020). Kampanye Pentingnya Himbauan Mencuci Tangan Melalui Media Pamflet di Masa Pandemi Covid-19. Jurnal Pembelajaran Pemberdayaan Masyarakat Vol 1 No 4 , 294-299.

Iswanto, S. (2018). Prospek Pusat Informasi dan Perpustakaan dalam Perkembangan Information and Communication Technology (ICT) : Tinjauan Komprehensif Nilai Filosofi Ilmu Informasi dan Perpustakaan. TIK Ilmeu Vol 2 Nomer 1.

Jahrir dkk. (2021). Pengaruh Penggunaan Bahasa Dalam Spanduk Lockdown Wilayah Terhadap Perilaku Sosial Masyarakat Pada Masa Pandemi Covid-19 di Kota Makassar. Jurnal Bahasa Dan Sastra Daerah Serta Pembelajarannya Vol 2 No 1.

Kemenkes RI. (2020). Info khusus Covid 19. https://covid19.kemkes.go.id/situasiinfeksi-emerging/situasi-terkini-perkembangan-coronavirus-disease-covid-19

Kundaryanti dkk. (2020). Faktor- faktor yang Berhubungan Dengan Perilaku Pencegahan Penularan Covid-19 Pada Ibu Hamil Tahun 2020. Skripsi Universitas Nasional.

Lestari, A. (2019). Hubungan Pengetahuan dan Sikap Terhadap Perilaku Cuci Tangan Pada Masyarakat Kelurahan Pegirian. Jurnal Promkes: The Indonesian Journal of Helath Production and Health Education Vol 7 No 1, 1-11.

Norita dkk. (2020). Hubungan Pengetahuan dan Sikap Dengan Kepatuhan Untuk Menjaga Jarak Dan Menggunakan Masker Pada Masyarakat Di Kota Barabai Kabupaten Hulu Sungai Tengah Tahun 2020.

Notoatmodjo. (2014). Ilmu Perilaku Kesehatan. Bandung: Alfabeta.

Notoatmojo, S. (2011). Ilmu Perilaku Kesehatan. Rineka Cipta. Jakarta.

Suprayitno dkk. (2020). Pengetahuan dan Sikap Masyarakat dalam Pencegahan Covid19. Journal of Health Science (Jurnal Ilmu Kesehatan) Vol 5 No 2 , 68-73.

Utami dkk. (2020). Pengetahuan, Sikap dan Keterampilan Masyarakat Dalam Pencegahan Covid-19 Di Provinsi DKI Jakarta. Jurnal Kesehatan Holistic. Vol. 4 No. 2.

Yogyakarta Tanggap Covid- 19. (2021). Dinkes DIY. yogyakarta: https://corona.jogjaprov.go.id/. 